\title{
THE RECONCILIATION OF THE DEVELOPMENT AND IMPLEMENTATION OF POLICE ACCOUNTABILITY IN THE UNITED KINGDOM
}

\author{
Shaka Yesufu ${ }^{1}$ \\ ${ }^{1}$ Department of Research and Development, University of Limpopo, Turfloop, Sovenga, Limpopo Republic of South Africa, 0727 \\ E-mail: shakazulu17@yahoo.co.uk \\ ORCID: https://orcid.org/0000-0001-8002-3074
}

ARTICLE INFO

Article history:

Received date 16.11.2021

Accepted date 23.12.2021

Published date 30.12.2021

Section:

Legal aspects in the system of social relations

DO I

$10.21303 / 2313-8416.2021 .002233$

KEYWORDS

Accountability

Constable

Constabulary independence

Discretion

Police

Policing
ABSTRACT

The objects of this research are: first, to explain some of the issues surrounding police accountability in the United Kingdom. Second, to make attempts in reconciling two opposing views as to whom police in the UK are accountable for? Third, to clarify the vagueness and ambiguous definitional concepts of the police constable, constabulary independence, and the use of police discretionary powers.

The author investigated the following problems: lack of police proper accountability, vague and ambiguous meaning of constabulary independence constable oath of office, and the use of police discretionary powers.

The main results of the research are: first, more clarity is needed as to whom is the British police accountable to? Second, a review of the current oath of office for police constable, the implementation of finding by previous committees set up by government: Lord Scarman, Rt Hon Christopher Patten, and Lord Nolan reports. Third, the monitoring of police officers' use of discretionary powers.

The area of practical use of the research: is for all citizens, directly or indirectly affected by police and safer communities. Criminal justice students in higher institutions and criminal justice practitioners, government officials, and policymakers.

(C) The Author(s) 2021. This is an open access article under the Creative Commons CC BY license

\section{Introduction}

Within the last hundred years, the British police have experienced some radical changes in both the legal framework and constitutional role of the police. Attempts to rework some legal changes and political practice have also transformed both the doctrine of constabulary independence and police governance. Some of the concerns raised by citizens over the years have been that the oath of office of the constable does not show that the police actually serving the people but the crown. Police accountability in the United Kingdom has been a consistent and fiercely debated issue, in some instances it places citizens in a state of dilemma as to whom does the police is accountable?[1].

\section{1. The object of this research}

The first, to explain some of the issues surrounding police accountability in the United Kingdom. Second, to make attempts in reconciling two opposing views as to whom police in the UK are accountable for? Third, to clarify the vagueness and ambiguous definitional concepts of the police constable, constabulary independence, and the use of police discretionary powers.

\section{2. Problem description}

It has become problematic within the field of social sciences to find an agreed definition of what police accountability means. Police accountability has various meanings. To some it may be seen as holding the police accountable to the people; to others, it may be seen as the external regulatory control of the police. Police accountability can; however, be understood from three contextual approaches: legal or organizational accountability, public accountability, and financial accountability. The author argues that a person is said to be accountable to another only when he/ she is made to account for their actions after a wrong has been done and they have no option but to comply with this requirement. Public institutions such as the police are expected to be accountable to the people who pay their wages and whom they are supposed to serve and protect. 
Police accountability is about citizens having expectations placed upon the police and individual officers to act responsibly within the confines of laid down laws, policies, and procedures. Police accountability ensures that police officers do not abuse their authority, carry out their duty fairly without fear or favour, protect all citizens regardless of race, class, or creed. Police accountability is about having an effective police complaints department transparent enough to gain the trust and support of citizens. Police accountability means police officers are answerable for their actions, acts, and conduct on or off duty. Police accountability means having police officers who are properly trained to understand and respect human rights. Police accountability promotes the weeding out of errant police officers and working in partnership with the community [2].

This article is one of several attempts to reconcile the vague and ambiguous role of the police constable in the United Kingdom. There is an ongoing state of confusion as to whom the constable is truly accountable to the crown or the people? This article is divided into four parts. In the introductory part of the article, the author looks at a few definitions of 'police accountability' provided to us by previous constitutional and police theorists, notably amongst them are the works of the following: [3, 4].

\section{3. Suggested solutions to the problem}

The author looks at the doctrine of 'constabulary independence' and the legal implications of police status in English law and police use of discretionary powers which sometimes lead to abuse of such powers resulting in violation of citizens' human rights. Holding police accountable is important for maintaining the public's confidence [5]. Effective accountability put in place enables the police to achieve their goal of lawfulness and legitimacy [6, 7].

In the third part of the article, the author looks at the police disciplinary code and police complaints procedure. In the final part of the article, the author looks at finding some solutions to police accountability in England and Wales.

Office of the constable.

The office of the constable is the bedrock of modern-day British Policing [8]. Every Constable is an independent legal entity; it is the public's guarantee of impartiality. Officers of the crown operate independently of undue influence, interference, and personal responsibility which require a unique type of person and commitment. Every sworn police officer in England and Wales is a constable, irrespective of rank. It is from the office of the constable that each officer derives their power. On appointment, each police officer makes a declaration to 'faithfully discharge their duties of the office of the constable'. It is very important to note, therefore, that in the UK, police officers only swear allegiance to the Monarch not to the people /citizens as many have claimed. The office of the constable means a police officer has the additional legal discretionary powers of arrest and control of the public given to him/her directly by a sworn oath of office and issue a warrant to carry out their constitutional mandate [9]. These powers associated with the office of the constable cannot be said to be delegated one but one that arises directly from the Crown and Police officers are deemed as servants of the Crown her majesty Queen of England.

The constable affirmation oath.

The constable affirmation oath of office states as follows that:

'I do solemnly and sincerely declare and affirm that I will well and truly serve the Queen in the office of constable, with fairness, integrity, diligence, and impartiality, upholding fundamental human rights and equal respect to all people and that I will to the best of my power, cause the peace to be kept and preserve and all offences against people and property and that while continue to hold such office, I will to the best of skill and knowledge discharge the duties thereof faithfully according to the law'[9].

Geoffrey Marshall [3], citing the case of Fisher v Oldham Corporation [1930] in explaining the concept of police accountability and constabulary independence argued that:

'the theory of constabulary independence has had a considerable impact on legislative accountability for police work. Local accountability has been hindered and its operations rendered uncertain both by the legal status of the constables and by the existence of the Home Secretary's statutory powers...For the doctrine that chief constables were not subject to control in law enforcement matters rested squarely upon the proposition that they were constables at Common Law and the notion that constables at Common Law exercised independence rested in turn upon the doctrine that they were not in a master and servant relationship with anyone for civil liability[10] 
Aim of the research was to reconcile the opposing views relating to police accountability in the United Kingdom

\section{Materials and Methods}

The author relies on researching secondary data about Police accountability, carried out an extensive literature review enabling him to gather information related to the topic under study. Secondary data is a process of carrying out a systematic review of previous literature as it relates to the research topic. It relives the author the burden of participation with research participants, who to identify, access to, and limited time frame available to conduct the research. In this study, the author collected secondary data from previous qualitative studies relating to the research topic. The author's main task was to ensure that the data analysed is not subject to any form of misinterpretation. In doing so, the researcher can rely on critical and reflective constant comparison of previous and present secondary data collected to arrive at an objective conclusion

\section{Results and Discussions}

One can gather from the above arguments of Marshall 1965, that the precise constitutional status of police constables remains ambiguous and not clearly defined under English law, and as a result, British citizens find it sometimes problematic to comprehend constables' roles, duties, and responsibilities. The intriguing source of controversy stemming from the above argument is that if indeed that it is assumed that the police are not in any master and servant relationship how can British citizens continue to hold on to the claim that the police are there to serve and protect the public? When in reality from the argument above provided to us by Marshall 1965 and consistent with the constable's affirmation oath stated above both don't appear to serve and protect citizens when looking at it from a legal perspective.

The author found the arguments presented to us by Lord Justice Denning in the case of R v MPC. Exparte Blackburn [1968] 2QB [11], is very important and very persuasive in understanding the concept of police accountability and issues relating to the concept of 'constabulary independence'.

In this case, Lord Justice Denning argued that

"Although the chief officers of police are answerable to the law, there are many fields in which they have a discretion with which the law will not interfere. For instance, it is for the commissioner of police, or the chief ...to decide on the disposition of his force and the concentration of his resources on any particular crime or area. No court can or should give him direction on such a matter. He can also make policy decisions and give effect to it ...he is not the servant of anyone, save of the law itself? No minister of the Crown can tell him that he must or must not, keep observation on this place or that; or that he must, or must not, prosecute this man or that one. Nor can the police authority tell him so. The responsibility for law enforcement lies on him. He is answerable to the law and to and to the law alone"

From the above conclusions drawn by Lord Justice Denning, one can understand why some British citizens have expressed their fears and are concerned that some police officers appear to be above the law. First, because the British criminal justice system has failed to effectively control errant police officers who have taken advantage of the whole system of lack of accountability to perpetuate harassment and brutality on vulnerable and marginalized citizens [11].

Lugarsten [4] wading into the debate of police accountability argues that 'a deep structural flaw in common law due to the failure to protect freedoms necessary for democratic participation in political life the protection of minority rights cannot be effective if it lived off and left to the courts'

The Scarman Report [12] states that accountability "renders the police answerable for what they do. Thereby it prevents them from slipping into an enclosed fortress of inward thinking and social isolation which would in the long term result in a siege mentality-the police in their fortress and the rest of us outside, unhappy, uncertain and insecure" The debate about police accountability reached its crescendo in the 1980s as a result of the policing of public disorder (riots), in particular the Brixton disorders 1981, the Toxteth riots, mass disturbances in Moss Side, and the events at Broadwater Farm, Tottenham 1985 and the Miner's strike 1984-5. Questions began to emerge as to who was in control of the police. Next, the author looks at the legal framework of police accountability, 
Legal Framework of Police Accountability.

Both the Police Reform and Social Responsibility Act 2011, Police Act 1964, and the Police Reform Act 2002 are important in understanding the background legal knowledge about police accountability. Public accountability and financial accountability.

The Police Reform and Social Responsibility Act 2011

The Bill covers five distinct policy areas: police accountability and governance; alcohol licensing; the regulation of protests around Parliament Square; misuse of drugs; and the issue of arrest warrants in respect of private prosecutions for universal jurisdiction offences.

Key areas of the police and social responsibility Act 2011:

- replaces police authorities with directly elected Police and Crime Commissioners, intending to improve police accountability;

- amends and supplements the Licensing Act 203 with the intention of 'rebalancing' it in favour of local authorities, the police and local communities;

- set out a new framework for regulating protests around Parliament Square. Relevant sections of the Serious Organised Crime and Police Act 2005 would be repealed and the police would be given new powers to prevent encampments and the use of amplified noise equipment;

- enables the Home Secretary to temporarily ban drugs for up to a year and remove the statutory requirement for the Advisory Council on the Misuse of Drugs to include members with experience in specified activities;

- introduces a new requirement for private prosecutors to obtain the consent of the Director of Public Prosecutions before the issue of an arrest warrant for 'universal jurisdiction' offences such as war crimes or torture. The Government's aim in introducing this change is to prevent the courts from being used for political purposes.;

First, the Police Reform and Social Responsibility Act 2011 enabled the election of the first Police and Crime Commissioners (PCC) in November 2012. It was the first of its kind in modern British policing, a paradigm shifts from police constabulary independence toward police democratic police protecting the interests of both the police and members of the public. Elected PCC's are mandated to swap the bureaucratic control of the police for democratic accountability for the benefit of all citizenship. Section 14 of the Policing Protocol 2011 clearly explains the following:

'The public accountability for the delivery of services and performance of the police is placed into the hands of the PCC on behalf of their electorate. The PCC derives are given the mandate to set and shape the strategic objective of their force area in consultation with the Chief constable. They are accountable to the electorate, and the Chief Constable is now accountable to their respective PCC. The [Police and Crime] Panel within each area force area is designed to have regular checks and balances on the performances of the PCCC in that context'.

The Police Act 1964 states that "It shall be the duty of the police authority to secure the maintenance of an adequate and efficient police force for their area, and to exercise for that purpose the powers conferred on a police authority by this Act" (s. 4(a)). The police authority offers advice to the chief constable concerning developing policing plans. It also scrutinizes the budget and expenditure of the police. Furthermore, the police authority has the power to appoint chief constables and can call on the chief constable to set the policing agenda.

It is important to mention here that PACE 1984 provided the statutory powers of the police in the investigation of offences and set limits for the use of police powers

For the chief constable to succeed in driving through changes in the police, he/she must be ready to carry along with them all members of the force. This was tested in the case $R \mathrm{~V}$ Secretary of State for the Home Department, ex p. Northumbria Police Authority [1988] WLR 590. The Northumbria Police Authority 'sought a judicial review of the decisions of the Home Secretary providing plastic ballistic bullets for riot control training in local forces where the police authority refused to sanction their purchase by the chief constable. The Court of Appeal rejected the Authority's case, holding that both under the 1964 Act and the Royal Prerogative the Home Secretary had a duty to do what he felt necessary for preserving the Queen's Peace' [13].

The Police Reform Act 2002.

The Act was introduced because of the shortcomings that existed in the tripartite process of police accountability. It can be argued that the major stakeholders in this arrangement were in a muddle. The Act had some radical proposals, including the introduction of an Annual Policing 
Plan, with the police authority required to produce a three-year strategy plan consistent with the National Policing Plan, and a statutory framework.

Section 15 of the Police Reform Act 2002 sets out clearly defined responsibilities of police authorities. They are to ensure that the Independent Police Complaints Commission has access to any police premises and materials/documentation within those premises during an investigation and to ensure that the investigating officers are given any assistance that they may reasonably require. The police authority is also required "To act as the "appropriate authority in the recording and investigation of complaints and conduct matters against officers of ACPO rank. This includes a statutory requirement to preserve evidence in such cases" [14].

Her Majesty's Inspectorate of Constabulary.

Further complicating the accountability system is Her Majesty's Inspectorate of Constabulary (HMIC). They are reputed for carrying out annual inspections and thematic reports to serve as a statutory regulatory body supervising the police. The HMIC has a duty under Section 54 of the Police Act 1996 to promote the efficiency and effectiveness of the police service, including police complaints and discipline [15, 16]. While Section 15 of the Police Reform Act2002 sets out the responsibility of HMIC to keep itself informed about the handling of complaints. The HMIC also has a role in advising individual police authorities about complaints made against Chief Police Officers. Next, the author looks at the concept of organizational Accountability

Organizational Accountability.

By organizational accountability, the author means that police accountability is provided through an established hierarchical rank structure. Within the rank structure, a requirement to obey orders is reinforced from top to bottom. The police have their disciplinary codes and conditions of service to enhance compliance and, if need be, appropriate sanctions and punishments are applied against errant police officers [8]

Public Accountability.

Public accountability can be explained from three perspectives namely: finance, performance, and fairness [17]. Finance is measured against service delivery, police budget, and expenditure, while performance is measured against local and national policing plans, fairness is measured against the level of citizens' satisfaction with police service delivery [14]. One measure of knowing whether policing is effective or not is to look at how citizens are responding to service delivery, sometimes can be measured against the total number or level of complaints [18] by members of the public and how effectively these complaints are dealt with [19]. Police accountability in this context also means general openness to public view and scrutiny [8]. The number of public complaints can sometimes be used as an indicator of police performance [20,21]. If the police are carrying out their function properly without fear or favour, there are few complaints. Most public complaints are borne out of dissatisfaction [22] misconduct by police officers, and a breach of policing procedures [18, 23].

True accountability cannot be said to exist without a fully democratic and locally-oriented structure for police accountability Democracy in this context as the author understands it means allowing the people to make choices about their policing needs and safety. It also means reinstating the ethos of community policing where all sections of society are allowed to participate in day-today matters of safety [12].

Financial Accountability.

The Conservative government attempted to incorporate a New Public Management model into policing, which led to the Sheehy Inquiry in 1993. According to Reiner [14], since 1992 the notion of accountability has shifted away from holding police power in check to businesslike notions of efficient, effective, and economic policing. Accountability has become accountancy. The practice of policing has become much more regulated by the central government, modeled on private-sector ideas and implemented by quasi-market mechanisms, seeking to achieve economical and efficient delivery of crime control above all else. This he referred to as "calculative and contractual accountability."

Local Police Authority.

This is one of the major stakeholders in the tripartite arrangement. The British public knows little about the role and composition of the police authority. In most places, the police authorities consist of two-thirds elected councilors and one-third magistrates. Most local police authorities in England and Wales comprise 17 members - nine appointed from local government, five local 
independents, and three magistrates. It is important to note that the new Tory-led government plans to abolish all local police authorities and promises to replace them with elected police crime commissioners.

\section{The London Metropolitan Police Authority.}

The MPA came into existence in July 2000. It was the first police authority for the whole of London. The MPA has 23 members, 12 London Assembly members appointed to the Authority by the Mayor of London [21]. The MPA has been abolished due to new police reforms under the Police Reform and Social Responsibility Act 2011.

The Metropolitan Police Authority priorities are:

- Hold the Commissioner rigorously accountable for the performance of the Metropolitan police service;

- Transform community engagement to help Londoners secure responsive policing;

- Work with the Metropolitan police service to achieve cultural change throughout the service so that everyone in London can gain and retain confidence in policing;

- Drive the Metropolitan police service to make the most effective, efficient, and cost-conscious use of its resources;

- Deliver a fit for purpose, efficient and effective Metropolitan Police Authority [14]

The Metropolitan Police Authority has the following duties: secure continuous improvement in the way policing is provided; publish an annual policing plan in consultation with London's communities; set policing targets and monitor performance regularly against those targets; be accountable for the management of the police budget, and oversee the appointment and discipline of senior police officers. The MPA prepares an annual budget for policing London and submits it to the Mayor, who has the responsibility for setting the budget in conjunction with the Greater London Assembly. The Commissioner is responsible for the "direction and control" of the MPS and, in discharging that function, must have regard to the Annual Policing Plan, published by the MPA, and to any guidance or code of practice issued by the Home Secretary [21].

The Police Reform and Social Responsibility Bill brought about radical changes to policing were introduced to parliament. Here are some of the proposals in the bill are as follows:

- making the police service more accountable to local people by replacing police authorities with directly elected police and crime commissioners to be introduced from May 2012;

- jverhauling of the licensing Act to give power to local authorities and police to tackle any premises that are causing a problem;

- the setting up of Crime committee consisting of 12 elected members of the London assembly to monitor the work of Mayor's Office for Policing and Crime (MOPAC). The MOPAC replaces the MPA and it's headed by the Mayor which makes him responsible for the direct control of the Metropolitan police, set out Metropolitan police strategic decisions at allocating resources, day to day operation of policing remains the responsibility of the police commissioner.

Some critics of the new policing governance in London have argued that consolidating too much power in the hands of the Mayor is undemocratic and it is not clear who checks the power of the Mayor in the event where there is an abuse of power by the Mayor concerning policing London. The Mayor may become too powerful for anybody to be in a position to control him. More importantly, the author argues that any police service that is subject to a politician's full control may act in the negation of Montesquieu's 'Separation of powers' doctrine of governance. The executive, judiciary, and legislature should function independently to avoid abuse of powers within a democratic state, and 'under such a system the police, it is feared, will become a partisan tool of a political constituency' [24].

Powers and Duties of the Chief Constable.

As Reiner [25] wrote, in an essay on police accountability, "the 1964 Act placed each force under the 'direction and control of the chief constable...Chief constables were required to give account for their decisions to various authorities, but were under no legal requirement actually to take account of any critical response."

Powers and Duties of the Home Secretary.

The Police Act of 1964 provided a basis for centralized government control. But policing in England and Wales is still not fully centralized. The chief constable still has a huge influence and autonomy within his/her force area. Over 60 percent of the police budget is paid for by the state. 
The Act provided the Home Secretary with an array of powers and established in statute the increasing dominance of central government within the framework of police governance: "He could require the chief constable to resign in the interests of efficiency, could call for reports into any aspect of the policing of an area and set up a local inquiry into policing matters" [26]. The Home Secretary also had powers and duties regarding qualifications for appointment and promotion, periods of service on probation, voluntary retirement, maintenance of discipline, suspension of officers from their force, duties which are or are not to be performed, and the hours of duty, leave, pay and allowances.

"The Home Secretary is answerable to parliament and the public for the provision of efficient and effective police service. The Home Secretary sets out the government's strategic priorities for policing in the National Policing Plan and has a role in helping to drive up police performance and addressing poor performance. It is the Home Secretary's responsibility to determine the total level of grant for policing and its allocation to police authorities, using a funding formula" (Morris Report 2004: 32).

\section{Complaints under the Police Reform Act 2002.}

This legislation sets out the current parameters in terms of those who can make complaints against the police. It is this Act that gave birth to the Independent Police Complaints Commission. Persons entitled to complain include the following: Any member of the public who alleges that they have been 'adversely affected by police misconduct, even if it was not directed at them; any member of the police service who claims to have witnessed misconduct by another police officer; any person acting on behalf of someone who falls within any of the categories above, for example, a member of an organization who has been given written permission (IPCC 2005).

The Police Complaints Authority was originally set up in 1985 as an independent body to investigate the police after an incident in which members of the public alleged that the police had behaved improperly.

Reiner (2000) argued that "police officers are rarely prosecuted for crimes arising out of a wrongful performance of their duties." The Director of Public Prosecutions and the Crown Prosecution Service have demanded stricter standards of evidence than those required for ordinary suspects before recommending the prosecution of police officers. It has been argued that the police complaints system should be left in the hands of independent investigators.

The author argues that the whole idea of police officers investigating their colleagues can scarcely be described as police accountability because it lacks credibility and transparency. These groups of investigators are responsible for the initial investigation of complaints against the police. It has taken over 30 years for the police to allow an independent complaints investigation procedure to be set up in Britain amidst stiff opposition from the Police Federation, a notable defender of the status quo. Some complainants are too frightened to make complaints against the police for fear of reprisals, a view confirmed by some of the participants who took part in the study [22]. First, the author welcomes the recent idea of third-party reporting centres where members of the public can make complaints against the police without the intimidating experience of going to the police station to make a complaint. Second, the author welcomes the new IPCC statutory guidance about changing the rules from "unsubstantiated" to "upheld" concerning the onus being placed on the complainant to prove cases of misconduct against errant police officers. The author suggests the need for a total civilianization of all police professional standards complaints and discipline departments, argues that all staff should be replaced by people with legal backgrounds and a few other staff whose wages are not paid by the police and who are employed directly by the Home Office, an approach currently being taken by the IPCC. Previous researchers have either failed to address this issue or paid little or no attention to it.

Lord Scarman warned that "if public confidence in the complaints procedure is to be achieved any solution falling short of a system of independent investigations for all complaints... which are not withdrawn is unlikely to be successful" [27].

Public Perceptions of the British Police Complaints System.

The public perception of the British police complaints system is mixed according to individual or group shared experience. A black person's perception of the complaints system may differ from white British perspectives. This does not necessarily mean that the complaints system does not work, but that it works differently for different people. Black youths who have been frequently 
stopped and searched by the police are more likely to complain against the police because they may see this practice as ongoing harassment by the police found out that initial perceptions of the police varied significantly amongst participants, from the sympathetic to the explicitly hostile [2]. These perceptions also had a strong impact on perceptions of the complaints process itself. They also found that "pro-police" participants tended to be older, white and middle-class, and tended to have the most positive perceptions of the police and, by extension, the complaints process. "Highly disengaged" participants, however, often tended to be young, black or minority ethnic participants living in inner cities. This group had the lowest level of trust in the police and had often experienced negative contact with officers. This group also tended to have the lowest level of faith in the police complaints procedure [7].

Next, the author looks at the issue of police discipline as this is important in conceptualizing police accountability. The author argues that had the police disciplinary code been working effectively, there would not have been a high number of complaints against the police. It is the failure of the police to abide by the disciplinary code that can be held responsible for the unhealthy relationship between police and black Londoners.

The Police Disciplinary Code.

The police, like many other British institutions, are regulated by a disciplinary code which forms part of the conditions of service. Police officers are fully aware of their roles and responsibilities. They are also made aware that any breaches of the code may result in sanctions if the officers are proved guilty. Police officers who are alleged to be in breach of discipline are first issued with a "Regulation 7" notice detailing the allegations and giving a timeframe for the officer to respond to the allegations. The level of punishment ranges from dismissal from the force, or a requirement that the officer resigns from the force to reduction in rank, reduction in the rate of pay for not more than 12 months, a fine, a reprimand, and caution or words of advice.

The general trend is that complaints against the police are going up. Two reasons may be responsible for this. First, people may be becoming more aware of their rights. Second, the public trust in the IPCC may have increased to reflect encourage more complaints. Third, the setting of reporting centres may have encouraged citizens to complain against the police. It is a risky enterprise to make a complaint against the police. There have been instances where complainants have been repeatedly harassed after such complaints were made; for example, police in Tottenham were reported to have stopped and searched Mr. Delroy Lindo about thirty times probably because he campaigned for Winston Silcott accused of PC Blakelock killing in 1995 Broadwater farm riots. Within several years after he complained about the police. Mr. Lindo successfully sued the police for racial harassment and the Metropolitan Police agreed to pay him compensation.

The author lists only the codes directly relevant to the subject matter of the study. They are the following:

1. Abuse of authority: occurs when an officer, without good and just cause, conducts a search, or requires a person to submit to any test or procedure, or makes an arrest, or uses any unnecessary violence towards any prisoner or any other person with whom he may be brought into contact in the execution of his duty, or improperly threatens any such person with violence, or is abusive or uncivil to any member of the public;

2. Racially discriminatory: behaviour towards another person because of their colour, race, nationality, or ethnic or national origins;

3. Criminal conduct: where a member of a police force has been found guilty by a court of law of a criminal offence;

4. It is also a disciplinary offence for a police officer to fail to comply with the codes of practice under the Police and Criminal Evidence Act 1984.

The police disciplinary code does not appear to be working, as most incidents of police misconduct are dealt with by words of advice. The police service needs to review its disciplinary code to ensure that it does not protect errant police officers whenever they break the law. They should be punished like anyone else. The days of enjoying immunity from prosecution should be a thing of the past. Errant police officers should be weeded out of the police service, not given a platform or "words of advice" authorizing them to continue to perpetuate injustices on vulnerable individuals and communities [7]. This needs to be urgently addressed as a matter of concern if the police are to win back the trust and confidence of all sections of British society. 
Human rights issues continue to challenge the systems of accountability in the United Kingdom. In recent years, disquiet has continued over diverse issues, including members of the public being shot by police officers in unlawful circumstances, the investigation of deaths in police custo$\mathrm{dy}$, and the questionable rigour and competence of investigations into murders of members of ethnic minority communities. The issue of race relations runs through many of these problems despite the raft of government and police self-imposed reforms embarked upon following the Macpherson inquiry, which branded the police service "institutionally racist." Human rights issues will continue to test the systems of police accountability in the United Kingdom [1].

Policing and Human Rights - the Pattern Report 1999.

Patten's report was constituted by the UK government to look into issues confronting the police in Northern Ireland. Patten 1999 defines accountability as it involves creating a real partnership between the police and community agencies, non-governmental organisations, families, citizens, a partnership based on openness and understanding of partnership in which policing reflects and responds to the community needs [28]. The Human Rights Act 1998 has established a new legal framework for policing in the UK concerning Article 8, Human Rights Act 1998 - The right to privacy should be respected concerning carrying out surveillance by the police. Most importantly, the "right to life" which is the most important of all universal human rights be respected. Without a right to life, other rights become meaningless. In Britain, if you look at the number of detainee's death in police custody under suspicious circumstances. It can be argued that the Police and Criminal Evidence Act 1984 is not always followed concerning preserving the rights of detainees which it was designed to protect whilst in police custody.

Patten [29] argues that the police should be accountable in two senses-'the subordinate or obedient sense and the explanatory and cooperative sense'. The subordinate sense is because police are employed by the community to provide a service and the community should have the means to ensure that it gets services. Explanatory and cooperative sense- the public and the police must communicate with each other and work in partnership, both to maintain trust and to ensure effective policing because policing is not a task for the police alone.

The author provides here some of Patten's recommendations as follows:

- There should be a new oath taken individually by all new and existing police officers, expressing an explicit commitment to upholding human rights. The constable affirmation oath of office was introduced over a century ago. The author argues that society has since evolved since then and that a new oath incorporating human rights principles, stating the police commitment and duty to serve the people must form part of the police conditions of service if we are to make police officers accountable to the people they serve and protect. These radical shift enumerated above is needed to do so;

- a new Code of Ethics should replace the existing, largely procedural code, integrating the European Convention of Human Rights into police practice;

- all police officers, police civilians should be trained (and updated regularly) in the fundamental principles and standards of human rights and the practical implications for policing. The human rights dimension should be integrated into every module of police training. This may lead to a reduction in deaths in police custody;

- the police service should take steps to improve its transparency. The presumption should be that everything should be available for public scrutiny unless it is in the public interest -not to police interests to hold it back;

- the creation of the office of Police Ombudsman. The Police Ombudsman should be seen as an important institution in the governance of Northern Ireland... the Ombudsman should play a proactive role in complaints received from members of the public against the police, should exercise the power to investigate even if no specific complaints have been received.

The concept of 'constabulary independence 'explained by Marshall [3], Lustgarsten [4] Walker [6] do not suggest in any way that police are accountable to the people but solely to the English laws. It can be argued that the laws alone cannot regulate the police themselves. The Director of Public Prosecutions (DPP) unwillingness to prosecute errant police officers and the use of discretion by police officers have also compounded matters that police are indeed above the law.

The author argues that police use of discretionary powers has been subjectively and strategically deployed by the police for over a century and it has no proper checks and balances put 
in place to monitor its abuse. There are no criteria set for the use of discretion or a guide on when the police can use their discretionary power. Discretionary powers can sometimes be subject to abuse by errant police officers. It is the minorities, marginalized, and members of the down below echelons of society that always feels the brunt of discretionary powers of the police as there is no identifiable control mechanism(s) to protect the most vulnerable groups in society. As police officers are a microcosm of the wider society, are bound to be influenced by, family values, culture, and socio-economic and racial differences.

Next, the author looks at the 'Nolan Principles' as a constructive forward in aligning the police more toward servicing the people than the crown.

Standards in Public Life (Nolan Principles).

The committee into public life was set up by the UK government in 1995, to look into related matters on Standards in Public Life. The committee was chaired by Lord Nolan and was tasked with making recommendations to improve standards of behavior in public life [30]. Some of the key recommendations are encapsulated into the following headings: selflessness; integrity; objectivity; accountability; openness; honesty; and leadership.

- selflessness: Holders of public office should take decisions solely in terms of public interest. They should not do so to gain financial or other material benefits for themselves, their family, or their friends;

- integrity: Holders of public office should not place themselves under any financial or other obligation to outside individuals or organisations that might influence them in the performance of their official duties;

- objectivity: In carrying out public business, including having a public appointment, awarding of contracts, individual rewards, and benefits. Holders of public office should be selected on merit;

- accountability: Holders of public office are accountable for their decision and actions TO the public and must submit themselves to whatever scrutiny is appropriate to their office;

- openness: Holders of public office should be as open as possible about all decisions and actions that they take. They should always give reasons for their decisions;

- honesty: Holders of public office have a duty to declare any private interests relating to their positions, duties and to take steps to resolve any conflict arising that protects the public interest;

- leadership: Holders of public office should promote and support the principles by leadership by example.

Limitations of the study.

First, this study is qualitative research relying on secondary data. No face-to-face interviews were conducted to hear directly from the police officers. Conducting a field study would have been more reliable in terms of data gathering and analysis of the data. The author is limited as to what should be done in contacting would-be participants. In an era of the Covid 19, it would be very problematic for most researchers to find would-be participants to take part in the study. The difficulty faced by researchers granting them audience into the secretive world of policing is another source of identified concern and this may limit further research on this topic.

\section{Conclusions}

The British constitution is ambiguous about the concept of 'police accountability'. It is the lack of a clear definition of what police accountability is, that creates an environment where individual police officers break the same law they are meant to enforce. Over the last five decades, we have seen several Inquiries into the police service in Britain leading to recommendations. The problem we have in Britain does not lie with the number of recommendations resulting from these inquiries but with the question of whether policymakers have the moral courage, time, and resources to implement these recommendations. What we have observed over the years is that partial implementations are often carried but quickly abandoned when the problems being addressed are no longer making headlines. For example, Lord Scarman recommended that more ethnic minorities be recruited into the police service, 18 years before Lord Macpherson stated a similar thing in his inquiry in 1999.

The author is convinced that if some of the Lord Scarman, Morris Report, Patten's recommendations, and the Nolan Principles are considered thoroughly and fully implemented in the United Kingdom. The police will become more accountable to the people. It is advised that our policing 
makers review some of these proposals with a view of implementing some of them. Finally, the confusing concept of "constabulary independence and police use of discretionary powers needs to be clearly defined within our legal framework in Britain. The author argues that more legal controls on executive and police powers, more avenues for effective and transparent complaints system are needed in Britain and that it is only by doing so before we can hold claim to proper police accountability in Britain, deeply rooted in the 'Peelian' tradition of policing by consent

\section{References}

[1] Mawby, R., Wright, L. (2005). Police Accountability in the United Kingdom. Written for the Commonwealth. London: Human Rights Institute, 18.

[2] Yesufu, S. (2013). The Development of Policing in Britain in the Next Five Years. The Police Journal: Theory, Practice and Principles, 86 (1), 66-82. doi: http://doi.org/10.1350/pojo.2013.86.1.556

[3] Marshall, G. (1965). Police and government, the status and accountability of the English Constable. London: Methuen.

[4] Lustgarten, L. (1986). The Governance of Police. London: Sweet \& Maxwell.

[5] Kleinig, J.(1996). TheEthics of Policing. Cambridge: Cambridge University Press. doi: http://doi.org/10.1017/CBO9781139172851

[6] Walker, N. (2000). Policing in a changing constitutional order. London: Sweet \& Maxwell, 297.

[7] Reiner, R. (2010). The Politics of the Police. Oxford: Oxford University Press.

[8] Yesufu, S. (2017). The Reality of Crime and Policing in the United Kingdom and South Africa. Cape Town: Reach Publishers.

[9] Police Federeration. Available at: http://www.polfed.org

[10] Case law: Fisher v Oldham Corporation (1930). KBD.

[11] Case law: R v MPC. Exparte Blackburn (1968) 2QB.

[12] Scarman, Lord Justice (1981). The Scarman Report. The Brixton Disorders. London: HMSO, Cmnd 8427.

[13] Reiner, R. (1997). Policing Cops, crime and control: Analysing the police function. Aldershot: Dartmouth.

[14] The Independent Police Complaints Commission (2005). Step by Step of how to make a complaint against the police. COM/10. London: IPCC.

[15] Her Majesty's Inspectorate of Constabulary (HMIC) (1997). Winning the Race: Policing Plural Communities. London: Home Office.

[16] Her Majesty Inspectorate of Constabulary (2000). Policing London: Winning Consent. London: Home Office.

[17] Reiner, R. (2000) The Politics of the Police. Oxford: Oxford University Press.

[18] Harrison, J., Cragg, S. (1991). Police Misconduct: Legal Remedies. London.

[19] Maguire, M., Corbett, J. (1991). A study of the Police Complaints system. London: HMSO.

[20] Independent Office for Police conduct report (2015).

[21] Morris, W. S. (2009). The Case for Change: People in the Metropolitan Police Service. Report of the Morris Inquiry. London: MPA.

[22] Brooks, D. (2003) Steve and Me: My friendship with Stephen Lawrence and the Search for Justice. London: Abacus, 320.

[23] Police complaints reach record high in England and Wales (2015). https://www.bbc.com/news/uk-34464181 Last accessed: 28.08.2021

[24] Brogden, M., Shearing, C. (1993). Policing for a New South Africa. London: Routledge, 248.

[25] Reiner, R. (1991). Chief Constables. Oxford: Oxford University Press.

[26] Jones, T. (2006). The governance and accountability of policing in T. Newburn. Handbook of Policing. Cullumpton: Willan.

[27] Loveday, B.; Mawby, R. (Ed.) (1995). Government and Accountability of the Police. Policing across the world. London: UCL Press.

[28] Christopher Patten 1999 report into Policing, UK.

[29] The Patten Commission Report on Policing in Northern Ireland, September 24 (1999).

[30] Lord Justice Nolan (1995). Standards in Public Life. First Report of the Committee on Standards in Public Life. 